\title{
a-Glucosidase Inhibitory Activity and Formulation of Solid Lipid Nanoparticle Containing Ethanol 70\% Standardized Extract of Kumis Kucing Leaves (Orthosiphon stamineus Benth.)
}

\section{(Aktivitas Penghambatan $\alpha$-Glukosidase dan Formulasi Solid Lipid Nanoparticle mengandung Ekstrak Etanol 70\% Daun Kumis Kucing Terstandar (Orthosiphon stamineus Benth.))}

\author{
RISMA MARISI TAMBUNAN $^{1 *}$, DENI RAHMAT ${ }^{1}$, WINDA DWI JULIYANTI ${ }^{1}$ \\ ${ }^{1}$ Faculty of Pharmacy, University of Pancasila, Srengseng Sawah, Jagakarsa 12640, South Jakarta
}

Submitted 4 January 2018, Accepted 16 February 2018

\begin{abstract}
Kumis kucing leaves (Orthosiphon stamineus Benth.) are one type of plants that is able to inhibit the activity of $\alpha$-glucosidase enzyme. This study aims to formulate Solid Lipid Nanoparticle from ethanol $70 \%$ standardized extract of kumis kucing leaves and which give $\alpha$-glucosidase enzyme inhibitory activity. The result of SLN characteristic for particle size of formula I, II and III shows the result of $51,60 \mathrm{~nm} ; 12.81 \mathrm{~nm} ; 11.87 \mathrm{~nm}$ and zeta potential of formula I, II and III show the results $-27.67 ;-10,7 ;-15.0$, respectively. The results of the $\alpha$-glucosidase enzyme inhibitory activity of the standardized extract, SLN formula I, II and III respectively showed IC50 of $132.9 \mathrm{ppm} ; 130.3 \mathrm{ppm}$; $131.4 \mathrm{ppm} ; 132.2 \mathrm{ppm}$ and Acarbose as comparison showed IC50 of $50.0 \mathrm{ppm}$. Data processing using t-test statistically at $\alpha=0,05$ showed that extract and SLN of formula I had significant difference, thus the best SLN formula was formula I with concentration of tween 80 and propylenglycol of $6 \%$ and $10 \%$.
\end{abstract}

Keywords: kumis kucing leaves, standardized extract, nanoparticle, solid lipid nanoparticle.

\begin{abstract}
Abstrak: Daun kumis kucing (Orthosiphon stamineus Benth.) adalah salah satu jenis tumbuhan yang mampu menghambat aktivitas enzim $\alpha$-glucosidase. Penelitian ini bertujuan untuk memformulasi Solid Lipid Nanoparticle dari ekstrak etanol 70\% daun kumis kucing terstandar dan yang memberikan aktivitas penghambatan enzim $\alpha$-glucosidase. Hasil karakteristik SLN untuk ukuran partikel formula I, II dan III menunjukkan hasil $51,60 \mathrm{~nm} ; 12,81 \mathrm{~nm} ; 11,87 \mathrm{~nm}$ dan zeta potensial formula I, II dan III menunjukkan hasil $-27,67 ;-10,7 ;-15,0$. Hasil aktivitas penghambatan enzim $\alpha$-glucosidase dari ekstrak terstandar, SLN formula I, II dan III masing-masing menunjukkan IC $_{50}$ adalah 132,9 ppm;130,3 ppm; 131,4 ppm; 132,2 ppm dan Akarbosa sebagai pembanding menunjukkan $\mathrm{IC}_{50}$ yaitu 50,0 ppm. Pengolahan data menggunakan $t$-test secara statistik pada $\alpha=0,05$ menunjukkan bahwa ekstrak dan SLN formula I memiliki perbedaan yang signifikan, sehingga formula SLN terbaik adalah formula I dengan konsentrasi tween 80 dan propilen glikol adalah $6 \%$ dan $10 \%$.
\end{abstract}

Kata kunci: daun kumis kucing, ekstrak terstandar, nanopartikel, solid lipid nanoparticle.

\footnotetext{
* Correspondence author, Hp: 08121306072

e-mail: rmu_tambunan@yahoo.com
} 


\section{INTRODUCTION}

INTERNATIONAL Diabetes Federation (IDF) states that the prevalence of Diabetes Mellitus (DM) in the world is $1.9 \%$ and has made DM as the cause of death of the seventh sequence in the world while in 2012 the incidence of DM in the world is as many as 371 million where the proportion of DM incidence type 2 is $95 \%$ of the world population who suffer from DM. The high prevalence of type $2 \mathrm{DM}$ is caused by unchanging risk factors such as gender, age, and genetic factors, the second is the modifiable risk factors such as smoking and alcohol consumption. Symptoms of diabetes include drinking lots, eating lots, rapid weight loss \pm 5 $10 \mathrm{~kg}$ in 2-4 weeks, and frequent urination. A person is diagnosed to have diabetes if the above symptoms occur for a long time with normal blood glucose levels $<140 \mathrm{mg} / \mathrm{dL}$ and fasting blood glucose $<100 \mathrm{mg} / \mathrm{dL}^{(1)}$.

Diabetes mellitus can be treated using oral antidiabetics with sulfonylureas, biguanides and inhibition of glucosidase or insulin-injectable enzymes. This therapy has side effects on the patient and requires a high cost. Therefore, an alternative way is needed with the use of medicines from natural materials. One plant that is efficacious as an antidiabetes is a kumis kucing leaves (Orthosiphon stamineus Benth.). Kumis kucing leaves contain essential oils, saponins, polyphenols, flavonoids, and potassium salts ${ }^{(2)}$. Based on research conducted by Ameria $^{(3)}$, phytochemical screening of ethanol 70\% extract of kumis kucing leaves has done and showed that kumis kucing leaves contain flavonoid, saponin, steroid, triterpenoid, tannin, quinone, coumarine and essential oil and on test of inhibition of enzyme $\alpha$-glucosidase with a dose of $225 \mu \mathrm{g} / \mathrm{mL}$ showed percent (\%) inhibition of $87.11 \%$ and IC50 131.2 $\mathrm{ppm}^{(3)}$.

In this experiment, ethanol $70 \%$ standardized extract of kumis kucing leaves was prepared, then was tested for $\alpha$-glucosidase inhibitory activity of the extract and Solid Lipid Nanoparticle (SLN). In this study the extract was formulated into a nanoparticle form, which is expected to have uniform size in the nano level so that contact with the enzyme becomes more effective. The nanoparticle technology performed by formulating Solid Lipid Nanoparticles (SLN) with cetyl alcohol as a matrix and varying the concentrations of tween 80 and propylene glycol in each of the formulas ${ }^{(5)}$.

\section{MATERIALS AND METHOD}

MATERIALS. Orthosiphon stamineus Folii Extractum Spissum, pure water, $\alpha$-glucosidase enzyme (G5003100 UN, Sigma), p-nitrofenyl- $\alpha$ D-glucopyranoside substrate (N1377-IG, Sigma), bovine serum albumin (A2153-10G, Sigma), acarbose (Bayer), sodium carbonate, sodium hydroxide, monobasic potassium phosphate, cremophor RH-40, cetyl alcohol, tween 80 , and propylenglycol.

METHOD. Preliminary Test or Optimization of Enzyme Conditions. Inhibitory Activity Test Against $\alpha$-glucosidase Enzyme from Ethanol 70\% Standardized Extract of Kumis Kucing Leaves. The enzyme solution was prepared by dissolving $1.0 \mathrm{mg}$ of $\alpha$-glucosidase enzyme in phosphor buffer solution ( $\mathrm{pH} 7$ ) containing $200 \mathrm{mg}$ of bovine albumin serum, previously used, enzyme diluted 10 times with phosphate buffer ( $\mathrm{pH} 7)$. The reactant mixture comprises $250 \mu \mathrm{L}$ p-nitrophenyl $\alpha$-D-glucopyranoside (p-NPG) $2 \mathrm{mM}$ as a substrate, $400 \mu \mathrm{L}$ phosphate buffer solution (pH 7) and $100 \mu \mathrm{L}$ sample solution in DMSO. Then the mixture was incubated at $37^{\circ} \mathrm{C}$ for 5 minutes, after which the enzyme solution was added $250 \mu \mathrm{L}$ and incubated for 15 minutes. The enzyme reaction was stopped by adding $\mathrm{Na}_{2} \mathrm{CO}_{3} 200 \mathrm{mM}$ as much as $1000 \mu \mathrm{L}$. Then the solution is measured at $405 \mathrm{~nm}$ wavelength. Acarbose is used as a reference standard with the same treatment as the sample. The experiment was done 3 times repetition.

Identification of raw materials. Manufacture of SLN (Solid Lipid Nanoparticles) Containing Ethanol 70\% Standardized Extract of Kumis Kucing Leaves. Preparation of SLN (Solid Lipid Nanoparticles) from ethanol $70 \%$ standardized extract of kumis kucing leaves begins with melting cetyl alcohol at a temperature of $8 \pm 5{ }^{\circ} \mathrm{C}$ until melting. Then cremophor RH-40 and standardized extract of kumis kucing leaves were added, then homogenized at $200 \mathrm{rpm}$ for 2 minutes (mixture A). Preheat the propylenglycol and water sufficiently at $80{ }^{\circ} \mathrm{C}$ then add tween 80 and mix A then homogenize at $200 \mathrm{rpm}$ for 5 minutes. Hot water was added to the mixture to $100 \mathrm{~mL}$ and homogenize with ultra turrax at 25000 rpm for 8 minutes. The temperature was set to $75 \pm 5$ ${ }^{\circ} \mathrm{C}$, then cooled. Homogenized back at $600 \mathrm{rpm}$ for 7 minutes then $800 \mathrm{rpm}$ for 8 minutes. Allow the SLN mixture to cool for 30 minutes and then stir the manual for 5 minutes. The formula of SLN (Solid Lipid Nanoparticles) from ethanol $70 \%$ standardized extract of kumis kucing leaves with variation concentration of propylenglycol and tween 80 can be seen on Table 1 .

Characterization of SLN (Solid Lipid Nanoparticles) containing ethanol $70 \%$ standardized extract of kumis kucing leaves:

a. Determination of distribution and particle size

b. Determination of potential zeta

c. Morphology 
Table 1. Composition of SLN formula of standardized extract of kumis kucing leaves.

\begin{tabular}{ccccccc}
\hline F & $\begin{array}{c}\text { Standardized } \\
\text { extract of kumis } \\
\text { kucing leaves }\end{array}$ & Cremophor RH-40 & $\begin{array}{l}\text { Propylene } \\
\text { glycol }\end{array}$ & Tween 80 & $\begin{array}{c}\text { Cetyl } \\
\text { alcohol }\end{array}$ & Water \\
\hline I & $1 \%$ & $2,5 \%$ & $10 \%$ & $6 \%$ & $2 \%$ & \\
II & $1 \%$ & $2,5 \%$ & $15 \%$ & $9 \%$ & $2 \%$ & Ad $100 \mathrm{~mL}$ \\
III & $1 \%$ & $2,5 \%$ & $20 \%$ & $12 \%$ & $2 \%$ & \\
\hline
\end{tabular}

Evaluation of SLN (Solid Lipid Nanoparticles) containing ethanol $70 \%$ standardized extract of kumis kucing leaves:

a. Organoleptic examination

b. Stability test

c. In vitro inhibitory activity against $\alpha$-glucosidase enzyme.

\section{RESULTS AND DISCUSSION}

The presence of ethanol $70 \%$ standardized extract of kumis kucing leaves and Solid Lipid Nanoparticles may provide inhibitory activity against the $\alpha$-glucosidase enzyme determined from the uptake of $p$-nitrophenol formed and measured by Absorbance Microplate Reader ELX 800 at a wavelength of $405 \mathrm{~nm}$. IC values indicate the concentration of extracts that can inhibit $50 \%$ of $\alpha$-glucosidase enzyme activity. Based on the results of this study $\mathrm{IC}_{50}$ from ethanol $70 \%$ standardized extract of kumis kucing leaves was $132.9 \mathrm{ppm}$ with $87.0 \%$ inhibition at $225.0 \mathrm{ppm}$ concentration. SLN (Solid Lipid Nanoparticles) formula $\mathrm{I}$ had $\mathrm{IC}_{50} 130.3 \mathrm{ppm}$ and $88.07 \%$ inhibition at $225.0 \mathrm{ppm}$, SLN formula II had IC $\mathrm{I}_{50} 131.4 \mathrm{ppm}$ and $87.65 \%$ inhibition at a concentration of $225.0 \mathrm{ppm}$, and SLN formula III has $\mathrm{IC}_{50} 132.2 \mathrm{ppm}$ and $87.34 \%$ inhibition at a concentration of $225.0 \mathrm{ppm}$. Acarbose

Table 2. Characterization of Solid Lipid Nanoparticle (SLN).

\begin{tabular}{ccc}
\hline Formula & Particle Size $(\mathrm{nm})$ & Zeta Potential $(\mathrm{mV})$ \\
\hline I & 51.60 & -27.67 \\
II & 12.81 & -10.7 \\
III & 11.87 & -15.0 \\
\hline
\end{tabular}

Table 3. Organoleptic test of SLN extract ethanol $70 \%$ of kumis kucing leaves.

\begin{tabular}{ccccc}
\hline Formula & Color & Smell & Taste & Form \\
\hline I & Brown & Slight & $\begin{array}{c}\text { Bitter, } \\
\text { slightly sour }\end{array}$ & Liquid \\
II & Brown & Slight & $\begin{array}{c}\text { Bitter, slightly } \\
\text { sour }\end{array}$ & Liquid \\
III & Brown & Slight & $\begin{array}{c}\text { Bitter, slightly } \\
\text { sour }\end{array}$ & Liquid \\
& & & sour
\end{tabular}

Table 4. Results of inhibitory activity and $\mathrm{IC}_{50}$ of SLN extract ethanol $70 \%$ of kumis kucing leaves.

\begin{tabular}{ccccc}
\hline No & Inhibitor & $\begin{array}{c}\text { Concentration } \\
(\mathrm{ppm})\end{array}$ & $\begin{array}{c}\% \\
\text { Inhibition }\end{array}$ & $\begin{array}{c}\mathrm{IC}_{50} \\
(\mathrm{ppm})\end{array}$ \\
\hline 1 & Acarbose & 225.0 & 91.38 & 50.0 \\
2 & Standardized & & 87.09 & 132.9 \\
& Extract & & & \\
3 & SLN I & 88.07 & 130.3 \\
4 & SLN II & 87.65 & 131.4 \\
5 & SLN III & & 87.34 & 132.2 \\
\hline
\end{tabular}

Table 5. Stability of SLN extract ethanol 70\% of kumis kucing leaves.

\begin{tabular}{cccccc}
\hline Parameter & \multicolumn{5}{c}{ Day } \\
& 1 & 2 & 3 & 4 & 5 \\
\hline Color & Brown & Brown & Brown & Brown & Brown \\
Turbidity & Stable & Stable & Stable & Stable & Stable \\
Sediment & - & - & - & - & - \\
\hline
\end{tabular}

has the highest activity of inhibiting $\alpha$-glukosidase enzyme because acarbose is a synthetic antidiabetic oral drug that has been proven to decrease blood glucose level and this drug belongs to the class of inhibitors of $\alpha$-glucosidase enzyme. In this study $\mathrm{IC}_{50}$ acarbose was $50.0 \mathrm{ppm}$ with an inhibition of $91.38 \%$ at a concentration of $225 \mathrm{ppm}$.

In this study, acarbose has the lowest $\mathrm{IC}_{50}$ value than the standardized extract, SLN (Solid Lipid Nanoparticles) of formula I, II and III. This is because acarbose is known to have a high inhibitory activity against $\alpha$-glucosidase enzyme. The standardized extract of kumis kucing leaves have an $\mathrm{IC}_{50}$ greater than SLN of formula I, II and III. This means the required concentration of the standardized extracts to inhibit $50 \% \alpha$-glucosidase enzyme activity than nanoparticle preparations. In this study showed when the the standardized extract was made into nanoparticles, the concentration required to inhibit

Picture 1. Acarbose inhibitory activity.

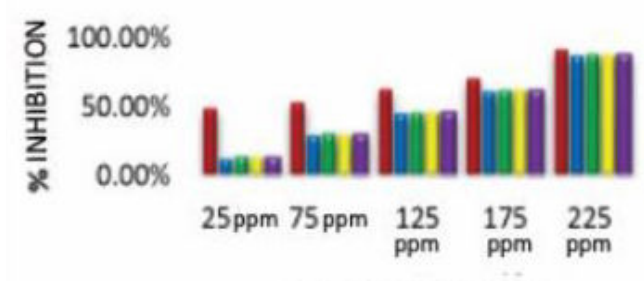

CONCENTRATION

Note: $n$ Acarbose

- standardized Extract

a SLNI

แ SLN II

I SLN III 
$50 \%$ of $\alpha$-glucosidase enzyme activity is getting smaller. In this SLN preparation which shows the smallest $\mathrm{IC}_{50}$ results are started from formulas I, II and III. Each Solid Lipid Nanoparticle (SLN) formula had a concentration difference of tween 80 and propylenglycol, which gives a difference of $\mathrm{IC}_{50}$ results in each of the formulas. The difference in surfactant concentration may affect the homegenity of a Solid Lipid Nanoparticle (SLN) preparation thereby affecting the $\mathrm{IC}_{50}$ yield on each of the respective formulas.

The SLN from ethanol 70\% standardized extract of kumis kucing leaves had uniform size in the nanometer level so that it can be released slowly and effectively in contact with the enzyme. This can also be due to the size of the nanometer having a larger surface area. Data processing using $t$ test statistically at $\alpha=0.05$ by processing $\mathrm{IC}_{50}$ data from extract and SLN formula I, extract and SLN formula II and extract and SLN formula III, showed that extract and SLN formula I had significant difference, therefore the best SLN formula is in the formula I with each concentration of tween 80 and propylen glycol of $6 \%$ and $10 \%$. SLN formula I has $\mathrm{IC}_{50} 130.3 \mathrm{ppm}$.

\section{CONCLUSION}

The ethanol $70 \%$ standardized extract of kumis kucing leaves can be formulated into Solid Lipid Nanoparticles (SLN). Extract and the SLN containing ethanol 70\% standardized extract of kumis kucing leaves have the inhibitory activity of $\alpha$-glucosidase enzyme with $\mathrm{IC}_{50}$ successively $132.9 \mathrm{ppm}$ and $130.3 \mathrm{ppm}$. Based on data processing using t-test statistically at $\alpha=0.05$ showed that the extract and SLN of formula I had significant difference, the best formula of SLN was formula I.

\section{REFERENCES}

1. Restyana Noor F. Diabetes melitus tipe 2. J Majority. 2015;5(4):93-94.

2. Victoria Cyntia YS. Pengaruh pemberian ekstrak daun kumis kucing (Orthosiphon aristatus) terhadap penurunan kadar glukosa darah tikus wistar yang diinduksi aloksan. Laporan hasil karya tulis ilmiah.2012:3.

3. Ameria. Penapisan fitokimia, uji toksisitas dengan metode BSLT dan uji aktivitas penghambatan enzim $\alpha$-glukosidase secara in-vitro ekstrak etanol $70 \%$ dari delapan jenis simplisia [skripsi]. Jakarta: Fakultas Farmasi Universitas Pancasila; 2014. 70-90.

4. Aryanto, Yateman. Nano di Indonesia. Jakarta: Keduputian Perkembangan Riptek Kementrian
Negara Riset dan Teknologi; 2007. 21-6.

5. Gupta, Ram B, Kompella, Uday B. Nanoparticle technology for drug delivery. volume 159 . New York: Taylor \& Francis Group;2006. 6-45.

6. Anu M, Sandeep K. Solid lipid nanoparticles - as novel lipid based nanocarriers for drugs. International Journal of Advanced Research. 2014. 2. 433-41.

7. Tegar GR, Noorma R, Tristiana E. Characterization of solid lipid nanoparticles p-methoxycinnamic acid (SLN-PMCA) formulated with different lipid component: stearic acid and cetyl alcohol. Pharma Scientia. 2012. 1(1):23-5. 